\title{
A HANDLIST OF THE WRITINGS OF GEORGE FREDERIC STILL
}

\author{
Compiled by ALFRED WHITE FRANKLIN, M.B., M.R.C.P.
}

This handlist is presented as a slender tribute to a pioneer-the first English doctor to devote his life to the study of disease in children. Still's writings record with living individual touch the medical opinions of one who. born into the clinico-pathological tradition of ninteenth-century medicine, helped in the struggle for sound etiological diagnosis and saw the dawning of the age of rational treatment.

\section{BOOKS}

1. THE DISEASES OF CHILDREx, BY JAMES FREDERIC GOODHART Sixth edition with the assistance of G. F. S. London 18998 xvi. 720.

Seventh edition 1902 xvi 813.

Eighth edition edited by G. F. S. London 1905 vii. 829 .

Vinth 1910 xvi. 931 Illustrated. Tenth 1913. Eleventh 1921 xv, 942. Twelfth 1925 xv, 966 . Originally published as THE STIDENT'S GLTDE TO
Or. Originally published as THE STLDENT'S GLIDE TO DISEASES OF CHILDREN BY JAMES FREDERIC GOOD-
HART London 1885 xii. 648 The eleventh and twelfth editions appeared after Goodhart's death.

2. COMMON DISORDERS AND DISEASES OF CHILDHOOD London Oxford University Press $19098^{\text {: xii, }}$ 731 Illustrated.

Second impression. April 1901; Third. April 1910. Second edition 1912

Third edition May 1915 xvi. 845

Impressions: Second. Oct. 1918: Third, Mar. 1920: Fourth. Feb. 1922

Fourth edition [1924] xvi. 965.

Fourth edition [1924] Xvi, 965

3. THE HISTORY OF PAEDIATRICS THE PROGRESS OF THE STLDY OF DISEASES OF CHID DREX LP TO THE END OF STLDY OF DISEASES OF CHILDREN LP TO THE END OF THE XVIITH CENTLRY Oxford University Press 63 plates.

Based on the FitzPatrick lectures 1928-9.

4. CoMmoN HAPPENINGS is CHILDHOD Oxford University Press London: Humphrey Milford 1938 $8^{2}$ viii $[x]-180$.

5. CHILDHOOD AND OTHER POEMS London John (1941] 8 xi. 152 .

most of the privately printed issue OTHER WRITINGS

6. Functional pyrexia in children Lancet. 1894. 1. 1239-40.

7. Diphtheria treated by antitoxin Brit. med. J.. 1894. 2. 180 .

3. On a form of chronic joint disease in children Med.-chir. Trans.. 1897, 80. 47-59 Reported Med.-chir. Trans.. 1897, 80. 47-59 Reported
Proc. R. Med -chir. Soc. 1898, n.s. 9, 10-15: Proc. R. Med.-chir. Soc.. 189
Brit. med. J.. 1896. 2, 1446-7.

9. Gumma of the spleen Trans. path. Soc. Lond. 1896-7. 48. 205-9 Reported Brit. med. J.. 1897, 1. 1160: Lancet. 1897, 1, 1274.

10. Acute abdominal distension in children Pediatrics. 1897. 4. 241-9.

11. Article on Rheumatoid arthritis in children In $\mathbf{A}$ SYSTEM OF MEDICINE Edited by T. C. Allbutt. London and New York. 1897, 3. 102-7.

12. The bacteriology of the simple posterior basic meningitis of infants Trans. path. Soc. Lond., 1897-8. 49. 313-27: also J. Path. Bact. 1898. 1183: Lancet. 1897, 2. 1048.

13. Congenital cystic liver with cystic kidney Trans. path. Soc. Lond.. 1897-8. 49, 155-65 Reported path. Soc. Lond. 1897-8. 49, 155-65 Reported
Brit. med. J., 1897, 2 1855: Lancet. 1898, 1.32.

14. Haemorrhage into the supra-renal capsules in infants Trans. path. Soc. Lond.. 1897-8. 49. 252-7 Reported Brit. med. J.. 1898. 1. 1200.

15. The micro-organism of simple posterior basic meningitis in infants Brit. med. J.. 1898. 2 , 1157-9: also Pediatrics. 1898. 6. 452-8.

16. Arthritis in childhood: its varieties and their diagnosis Clin. J.. 1898, 11, 388-93: also Indian med. Rec., 1898. 15. 453.

17. Remarks in discussion on Rheumatic heart disease in children Brit. med. J.. 1898. 2. 1134 .
Some aspects of congenital syphilis in children Loc. cit.. 1154.

Movable kidney in children Loc. cit.. 1155 The treatment of hydrocephalus by intracranial drainage Loc. cit.. 1157.

18. Ervthema enematogenes (enema rash) in children Trans. clin. Soc. Lond.. 1899. 32 11-17 Reported Brit. med. J.. 1898, 2, 1255: Lancet, 1898, 2. 1062 .

19. Tubercular uker of the stomach in children Trans. path. Soc. Lond.. 1898-9. 50. 76-83 Reported Brit. med. J., 1899. 1. 1092.

20. Congenital hypertrophy of the pylorus Trans. path. Soc. Lond.. 1898-9. 50. 86-98 Reported prit. med. J.. 1899. 1. 340: Lancet. 1899. 1, 375.

21. Biliary calculi in children Trans. path. Soc. Lond. 1898-9.50. 151-8 Reported Brit. med. Lond.. 1898-9. 50, 151-8 Reported Brit
J. 1899. 1.851: Lancet. 1899. 1. 963.

22. The histology of the rheumatic nodule (F. J. Poynton and G. F. S.) Trans. path. Soc. Lond., 1898-9. 50. 324-8 Reported Brit. med. J., 1899. 1. 851: Lancet. 1899. 1. 962.

23. Observations on oxvuris vermicularis in children Brit. med. J.. 1899. 1. 898-900.

24. Serous expectoration after puncture Brit. med. J.. 1899. 2. 454. 688 .

25. Observations on the morbid anatomy of tuberculosis in childhood. with special reference to the primary channels of infection Brit. med. J.. 1899. 2. 455-8: also Pediatrics. 1899.8, $335-46$.

26. The channels of tubercular infection in childhood Clin. J.. 1899. 14, 363-7 Reported Lancet. 1899. 2. 459 .

27. Day-terrors (pavor diurnus) in children Lancet, 1900. 1. 292-4: also Rif. med. Palermo, 1900, 1. $31-32$.

28. Cream and fat in infant feeding Practitioner, 1900. 64. 611-21

29. Mongolian imbecility King's Coll. Hosp. Rep. $1900.6,51-61$.

30. Tuberculosis of the female generative organs in childhood Trans. path. Soc. Lond.. 1900-1. 52 139-43 Reported Brit. med. J.. 1901. 1, 958: Lancet. 1901.1.1141.

31. Rheumatism in childhood Practitioner. 1901. 66, 53-63.

32. Jaundice in children Clin. J.. 1901. 17. 321-6: also Med. Pr. 1901. n.s. 71. 436-8: Ann. Med. Chir. inf. 1901. 5. 472-9: -4llg. nien. med. Ztg., 1901. 46. 535-6. 546-7.

33. Abdominal tuberculosis in children Clin. J., 1901. 19. 113-20.

34. Unusual case of obesity in a child Trans. clin. Soc. Lond. 1901, 34. 243-4 Reported Brit. med. J.. 1901, 1. 1080: Lancet. 1901, 1, 1275, and 1276 .

35. Observations on suppurative pericarditis in children Brit.med.J. 1901. 2. 606-8.

36. Tuberculosis in childhood Practitioner. 1901. 67. 91-103.

37. Nervous children King's Coll. Hosp. Rep.. 1901, 7. 41-51

38. Report of the department for diseases of children (Oct. 1899-Dec. 1900) Loc. cit.. 329-39.

39. The Goulstonian lectures on some abnormal psychical conditions in children Lancet. 1902. 1. 1008-12 1077-82, 1163-8: the third lecture reprinted .4mer. Practit.. 1903. 35, 87-102.

40. Letter on Threadworms and appendicitis Lancet, 1902. 2. 125

41. Case of bullous and haemorrhagic eruption (G. F. S. and A. Whitfield) Reported Lancet, 19022157

42. Nephritis in children King's Coll. Hosp. Rep.. 1903. 8. 19-30. 
43. Report of the department for diseases of children (Jan.-Dec. 1901) Loc. cit., 361-76.

44. Convuksive disorders in infancy Clin. J., 1903, 21, $100-7$.

45. Diseases of children: a review of recent work Practitioner, 1903, 71, 815-31.

46. Remarks in discussion on Congenital hypertrophic stenosis of the pylorus Med.-chir. Trans. $1903,68,510$.

47. A lecture on the modification of cow's milk for infant-feeding Clin. J., 1904, 23, 81-88.

48. Syphilis in children Practitioner, 1904, 73, 94-110: aks Pediatrics, 1904, 16, 577-93.

49. Nephritis in infantile scurvy Lancet, 1904, 2 , 441-2.

50. A lecture on infantile syphilis Lancet, 1904, 2 ,

51. Some recent work in diseases of children Practi-
. tioner, 1905, 74, 217-31: also Pediatrics, 1905 , $17,547-61$

52. On the diagnosis and treatment of hypertrophy of the pylorus in infants Lancet, 1905, 1, 632-6 Abstracted in Polyclinic, 1905, 9, 113-5.

53. On the use and abuse of condensed mill and patent foods in infant-feeding Practitioner, 1905, 75, 462-9.

54. A lecture on habit spasm in children Lancet, $1905,2,1754-7$.

55. Pyrexia of obscure causation in children Reported Lancet, 1906, 1, 163.

56. Some recent observations on diseases of children Practitioner, 1906, 76, 666-78: also Pediatrics, $1907,19,261-72$

57. A clinical bocture on infantile scurvy Brit. med. J., 1906, 2, 186-90: aks Pediatrics, 1907, 19, $206-19$

58. Clinical observations on the cerebral palsies of children with special reference to aetiology 37-44 Reported Lancet, 1906, 1, $1200-1$.

59. Remarks on Congenital syphilis (Hunterian Society discussion) Reported Brit. med. J., 1906, 1 , 1345: Lancet, 1906, 1, 1323-4.

60. A lecture on head-nodding with nystagmus in infancy Lancet, 1906, $2,207-9$.

61. A lecture on infantile paralysis Clin. J., 1906 23, 225-31.

62. Recent work in diseases of childhood Practitioner, 1907, 79, 550-61.

63. On head-rolling and other curious movements in children Clin. J., 1907, 29, 87-91.

64. On white-wine whey in infant feeding (B. Myers and G. F. S.) Lancet, 1907, 1, 78-79.

65. A lecture on enuresis and feecal incontinence in children Clin. J., 1907, 30, 17-24.

66. The medical aspects of dental caries in childhood Brit. med. J., 1907, 2, 1485-7 Abstracted Med. Pr., 1907, n.s. 4,170 Reported Lancet, 1907, 2451.

67. A clinical lecture on infantile diarrhoea Med. Pr. 1907 , n.s. 84, 212-5.

68. Article on Rickets in A sYsTry of MDICTNF edited by William Osler, London, 1907, 1, 864-92 And slightly revised in Second edition, London, 1915, $2,775-98$.

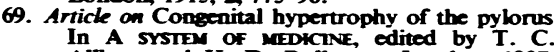
Allbutt and H. D. Rolleston, London, 1907, 3, 515-22.

70. A case of cleido-cranial dysostosis Trans. med. Soc. Lond., 1908, 31, 350-2 Reported Lancet. $1907,2,1388$.

71. Hairball in the stomach Proc. $R$. Soc. Med. (Clin. Sect.), 1907-8, 1, 212-4 Reported Brit. (Clin. Sect.), 1907-8, 1, 212-4 Reported Brit.

72. A clinical lecture on indiestion in children Med. Pr., 1908, n.s. 85, 256-8.

73. Some recent work in disease of children Practitioner, 1908, 81, 702-10.

74. A clinical lecture on infantile marasmus Med. Pr., 1908, n.s. 85, 604-6.

75. Article on Congenital syphilis In A systey of SYPHIIs, edited by D'Arcy Power and $J$ Keogh Murphy, London, 1908, 1, 281-368 18 plates.

76. Preface to How To NURse sick CHmDnen by the late Charles West, M.D. New edition. London, etc., 1908.

77. Enlarged tonsils and “ adenoids" Clin. J., 1911, 37, 71-6.

78. Pyelitis in children Pediatrics, 1912 24, 605-13.

79. Remarks in discussion on Affections of the heart in childhood Reported Brit.med J 1913, 2792.

80. Remarks in discussion on The diagnosis and treatment of acute infammatory affections of the abdomen in children Reported Brit med. J., 1913, 2, 806: Lancet, 1913, 2, 404.

81. Article on Oedema in children In Disenses of CFIIDREN, edited by A. E. Garrod, F. E. Batten, and H. Thursfield, London, 1913, 129-137.

82. Epidemic stupor in children (F. E. Batten and G. F. S.) Lancet, 1918, 1, 636.

83. The Lumian lectures on coeliac disease Lancet, $1918,2,163-6,193-7,227-9$.

84. Infantile scurvy: the antiscorbutic factor of lemon juice in treatment (A. Harden, S. S. Zilva, and G. F. S.) Lancet, 1919, 1, 17-18.

85. Some eventcenth-century writings on diseases of children In CONTRBaUnONS TO MIDICAL AND children In CONTRBBUTONS TO MEDKCAL AND OSLE, New York, 1919, 1, 177-91.

86. Orbital haemorrhage with proptosis in experimental scurvy (S. S. Zilva and G. F. S.) Lancet, 1920, 1, 1008.

87. Remarks in discussion on The present position of vitamins in clinical medicine Brit. med. J., $1920,2,155-6$.

88. Cephalic bruits in children Brit. J. Child. Dis. 1921, 18, 173-9.

89. Appreciation of Sir Sydney Beauchamp Brit.med. J., $1921,2,969$.

90. On chronic intussusception in children Arch. Pediat., 1921, 38, 174-9: akso Clin. J., 1922, 51, $37-40$.

91. Letter on Physical education of girls Brit. med. J., 1922, 1, 501 : also Med. Pr., 1922, n.s. 113,

92. Attacks of arrested respiration in the new-born Lancet, 1923, 1, 431-2.

93. A British Medical Association lecture on con genital hypertrophy of the pylorus Brit. med. J., 1923, 1, 579-81.

94. The treatment of cyclic vomiting Lancet, 1923, 1, $1327-8$.

95. Entargement of the abdomen in childhood Clin. J., 1924, 53, 193-8.

96. The treatment of infantile scurvy Proc. $R$. Soc Med. (Sect. Therap. and Pharm.), 1925, 18, Med. (Sect. Therap. and Pharm.), 1925, 18,

97. Appreciation of John Thomson Brit. med. J. 1926, 2, 95-96.

98. Case reports of Polyarthritis with scleroderma Syphilitic pseudo-osteo-arthritis, Two cases of cardiospesm Proc. R. Soc. Med. (Sect. Dis. Child.), 1926-7, 19, 62

99. Ingleby lectures on place-in-family as a factor in disease Lancet, 1927, 2, 795-800, 853-8.

100. Letter on Paediatries or pediatries Brit. med. J. $1928,2,867$.

101. Articles on Infantile scurvy (Barlow's disease) and Some forms of oedema in childhood In Deses of CHIDRen, edited by A. E. Garrod F. E. Batten, and H. Thursfield, Second edition, F. E. Batten, and H. Thursfield, Second edition, London, 1929, 131-143, 143-152, Reprinted in third

102. Congenital anorexia Practitioner, 1930, 125, 49 53.

103. Carmen Scholae Medicinac Song of the Medical School of King's College Hospital Words by G. F. S. Music by H. Tyrrell Gray [1930] Ako King's Coll. Hosp. Gaz., 1930, 9, 201-3.

104. Second attacks of acute poliomyelitis, and the minimal duration of immunity Arch. Dis. Childh., 1930, $5,295-8$.

105. Letter on Taxation of cod-liver oil Lancet, 1932. $2,919$.

106. Prevention of disease in infancy Lancet, 1933, 2 $1103-7$.

107. Presidential speech of thanks. Third International Paediatric Congress, London, 1933 Acta Paediatr., Stockh., 1933, 16, xxx.

108. Tiredness as a symptom in childhood Practitioner, $1935,134,385-92$.

109. Infantile scurvy: its history Arch. Dis. Childh. 1935, 10, $211-8$.

110. The pre-school child Reported Lancet, 1935, 1 , 819.

111. Perspective in medicine King's Coll. Hosp. Gaz 1936, 15, 3-12 Reported Lancet, 1935, 2896. Diseases of children at King's Colleoe Hospital King's Coll. Hosp. Gaz., 1939, 18, 63-67.

113. Disease in children Brit. Encycl. Med. Pract. Supp. 1939 London, 37-42.

Sir Frederic Still edited and prefaced the King's College Hospital Pharmacopoeia for 1901, Colleze Hospital 